\title{
Daily activity, diet and habitat of Bali myna (Leucopsar rothschildi) in Nusa Penida, Bali, Indonesia
}

\author{
FRANSISCUS XAVERIUS SUDARYANTO ${ }^{1, \vartheta}$, SATYAWAN PUDYATMOKO ${ }^{2}$, \\ TJUT SUGANDAWATY DJOHAN ${ }^{3}$, JUSUP SUBAGJA ${ }^{3}$, I WAYAN SUANA ${ }^{4}$, \\ LALU ACHMAD TAN TILAR WANGSAJATI SUKMARING KALIH ${ }^{5}$, JUNITA HARDINI ${ }^{1}$, \\ JOBNICO SUBAGIO ${ }^{1}$ \\ ${ }^{1}$ Department of Biology, Faculty of Mathematics and Natural Sciences, Universitas Udayana. Jl. Raya Kampus Unud No. 9, Jimbaran, Badung 80361, \\ Bali, Indonesia. Tel.: +62-361-701954, "email: sudaryanto@unud.ac.id \\ ${ }^{2}$ Department of WildLife Conservation, Faculty of Forestry, Universitas Gadjah Mada. Jl. Agro 1, Bulaksumur, Sleman 55281, Yogyakarta, Indonesia \\ ${ }^{3}$ Department of Ecology and Conservation, Faculty of Biology, Universitas Gadjah Mada. Jl. Teknika Selatan, Bulaksumur, Sleman 55281, Yogyakarta, \\ Indonesia \\ ${ }^{4}$ Department of Biology, Faculty of Mathematics and Natural Sciences, Universitas Mataram. Jl. Majapahit No. 62, Mataram 83126, Nusa Tenggara \\ Barat, Indonesia \\ ${ }^{5}$ Department of Fisheries Resources Utilization, Faculty of Fisheries, Universitas 45 Mataram. Jl. Imam Bonjol, Mataram 83239, Nusa Tenggara Barat, \\ Indonesia
}

Manuscript received: 23 July 2020. Revision accepted: 4 September 2020

\begin{abstract}
Sudaryanto FX, Pudyatmoko S, Djohan TS, Subagja J, Suana IW, Kalih LATTWS, Hardini J, Subagio J. 2020. Daily activity, diet, and habitat of Bali myna (Leucopsar rothschildi) in Nusa Penida, Bali, Indonesia. Biodiversitas 21: 4474-4482. Endemic Bali myna (Leucopsar rothschildi) has a very high risk of extinction in its natural habitat. Bali Barat National Park (BBNP) and other NGO's have conducted various conservation activities, such as breeding and release, community development, environmental improvement, and awareness program. Breeding and release have already been applied in Nusa Penida out of its original habitat. To support the conservation of Bali myna, basic ecological data are needed, eg. daily activities, habitat profile, home range, and interspecific interaction. This study aimed to meet the needs of these vegetation profiles. We collected data from 2013 to 2015. Daily activities were observed on a couple of Bali myna in a nest box at agroforestry area. Habitat profile was determined by analyzing vegetation at their foraging, nesting, and resting areas, using a quadrate plot of $20 \times 20 \mathrm{~m}^{2}$. To estimate the home range, of the Bali myna, we recorded 700 points of perching of these birds, by using Global Positioning System, and analyzed using Convex Polygon Method. Their interaction with other animals was carried out at their foraging, nesting, and roosting areas. Daily activities of the Bali myna in Nusa Penida are predominantly recorded in agroforestry areas, so its home range is relatively narrow, at 3.9 ha. The food types of Bali myna in Nusa Penida were fruits, insects, and nectar flowers. Sucking on nectar flower is the first report here. The vegetation profile of nesting and foraging area for Bali myna consists of one layer of thick and dense canopy, while the vegetation profile of resting area is not too dense, which is composed of two canopy layers. Bali myna's interactions with other animals for competition, predation, and mutualistic symbiosis. These data are expected to be used to make decisions in order to conserve Bali myna in Nusa Penida.
\end{abstract}

Keywords: Bali myna, daily activity, habitat profile, home range, interspecific interaction

\section{INTRODUCTION}

Bali myna (Leucopsar rothschildi Stresemann, 1912) is endemic to Bali Island, specifically to Bali Barat National Park (BBNP) since 2005 (Sudaryanto et al. 2015). Bali myna was first discovered by Erwin Stresemann in 1911 in Bubunan-Buleleng, but in the 1950s it was no longer found there. Between the 1960s and 1990s Bali myna still existed in Selemadeg-Tabanan, Melaya-Jembrana, and PupuanTabanan (van Balen et al. 2000). In the 2000s Bali myna was only found in Brumbun Station to BBNP Red Light Station and in 2014 it was only in BBNP Red Light Station (Sudaryanto et al. 2015).

Bali myna has a very high risk of extinction in its natural habitat at BBNP, because many poachers (Figure $1)$, so it is included in the Critically Endangered category in the International Union for Conservation of Nature and Natural Resources Red List of Threatened Species
(BirdLife International 2018). Bali myna is also protected by the Government of Indonesia through the Regulation of Ministry of Environment and Forestry No. P.106/MENLHK/SETJEN/KUM.1/12/2018, concerning protected plant and animal species (Kementerian Lingkungan Hidup dan Kehutanan 2018). Bali myna is also included in Appendix I of Convention on International Trade in Endangered Species of Wild Fauna and Flora, because, between 1960 and 1980, Bali myna was caught and exported to meet the market demands in Europe (van Balen et al. 2000; Convention on International Trade in Endangered Species of Wild Fauna and Flora 2019).

In the efforts to conserve Bali myna, BBNP has released Bali mynas several times into its natural habitat. In 2007, 72 Bali myna was released by Tegal Bunder Bali myna Breeding Center and Asosiasi Pelestari Curik Bali. Since then, every year at least 20 Bali myna specimens are released into the wild (Hernowo 2017). Yayasan 
Pecinta/Penyantun Taman Nasional or Friends of the National Parks Foundation (FNPF) also released Bali myna in Nusa Penida. This foundation works closely with the Traditional Village or Desa Adat in Nusa Penida to include bird protection, especially Bali myna, in awig-awig or the local custom law. In 2004 in Pet there were 16 Bali myna specimens and 15 nests boxes. (Yayasan Pecinta/Penyantun Taman Nasional 2018; Sudaryanto et al. 2019a).

To support the conservation of the Bali myna in Nusa Penida, Bali, Indonesia basic data are needed and this, includes: daily activities, habitat profile, home range, and interspecific interactions of the Bali myna. This paper reported on the basic needs of the Bali myna, which can then be used to make decisions in efforts to conserve Bali myna in Nusa Penida.

\section{MATERIALS AND METHODS}

\section{Study area}

The landscape of Nusa Penida Island, Bali Province, Indonesia is different from the mainland of Bali Island. Nusa Penida has a limestone base and karst topography with the latosol soil types of wooded grassland whose water availability is very poor. The average rainfall is only $972 \mathrm{~mm} /$ year. In the lowlands, an altitude of 0 to 130 meters above sea level ( $\mathrm{m}$ asl.), there are agroforestry and grasslands. Agroforestry activities are generally located at the back of settlement areas, planted with a variety of cultivated plants among large trees that are naturally grown. Grasslands are found in open areas, which are usually planted with coconut trees. Livestock, such as Balinese cattle, are usually herded in this pasture. Pristine forest is found at an altitude of 200 to 250 masl. Various large trees which are natural stands are found in this forest. These large trees hold rainwater and drain it into natural ponds where the water is very clear at the bottom of a cliff. The study conducted at agroforestry area in Ped Village (Figure 2), from 2013 to 2015.

\section{Procedures}

Observation of Bali myna's daily activities

Observation of Bali myna's daily activities was conducted on a couple of birds in a nest box on Artocarpus heterophyllus tree in agroforestry area. These birds are the offspring of birds that released before, since they were not ringed. Observations were conducted using a binocular telescope with Scan Sampling Method (Martin and Bateson 2012). Interval of observation was five minutes. Observation started at 5:00 until 19:00, since Bali myna is active between 05:30 to 18:30. The observers were divided into three shifts, i.e. $05: 00$ to $10: 00,10: 00$ to $15: 00$, and 15:00 to 19:00. There were two observers in each shift. The Bali myna's daily activities observed were: flying, walking, fruit feeding, insect feeding, nectar sucking, preening, crested, bobbing, vocalization, drinking, bathing, nesting, brood, and parenting. Identification trees and insects to activity and feeding of Bali myna.

\section{Observation of Bali myna's habitat profile}

Profile of Bali myna's habitat was determined by analyzing vegetation at foraging, nesting, and resting areas. We used a quadrate plot of $20 \times 20 \mathrm{~m}$ for sampling vegetation, and we used 9 plots (Sudaryanto et al. 2019b). In each plot, we measured and recorded: species of tree, number of each species, total of tree height, the first branch height, canopy width, canopy length, canopy thickness, diameter of tree at breast height, position of tree (distance to the $\mathrm{x}$ and $\mathrm{y}$ axis), then vegetation profile is made. Tree height was measured by using a Hagameter.

\section{Observation of Bali myna's home range}

In order to estimate the home ranges of a couple of Bali myna specimens with ring, we recorded at 700 points of perching of a couple of Bali myna, by using Global Positioning System (GPS). Furthermore, the outermost points were connected and constituted the Diurnal Activity Center (DAC), which is an area that is routinely used by these birds during the day.

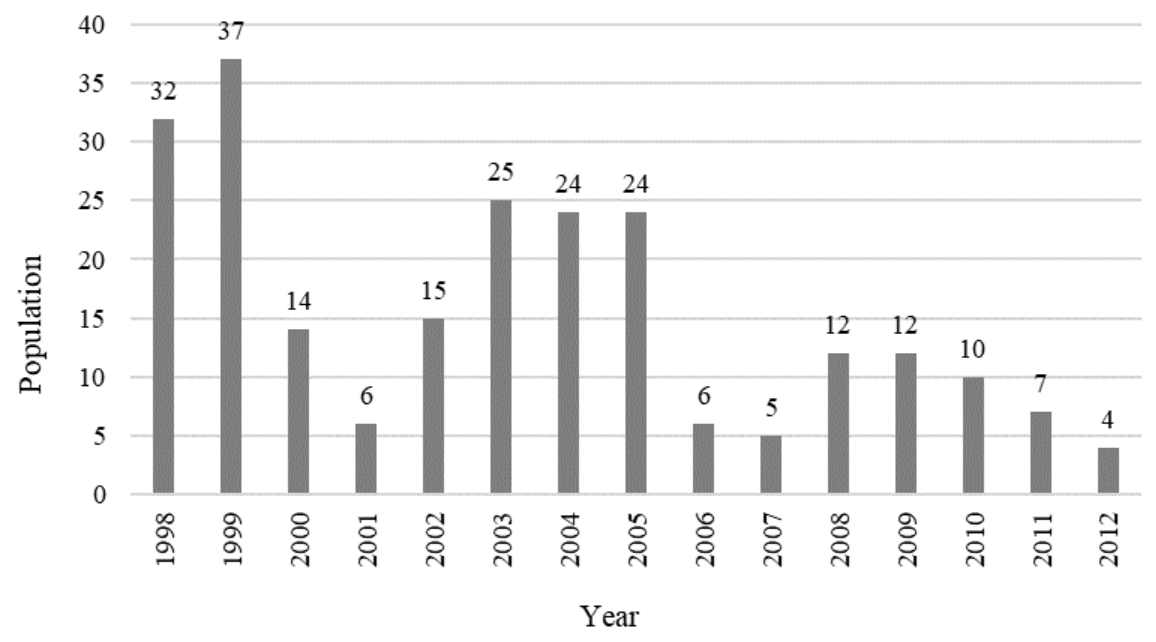

Figure 1. Population Bali myna in Bali Barat National Park, Indonesia (van Balen et al. 2000; Sutito et al. 2012; Sudaryanto et al. 2015) 


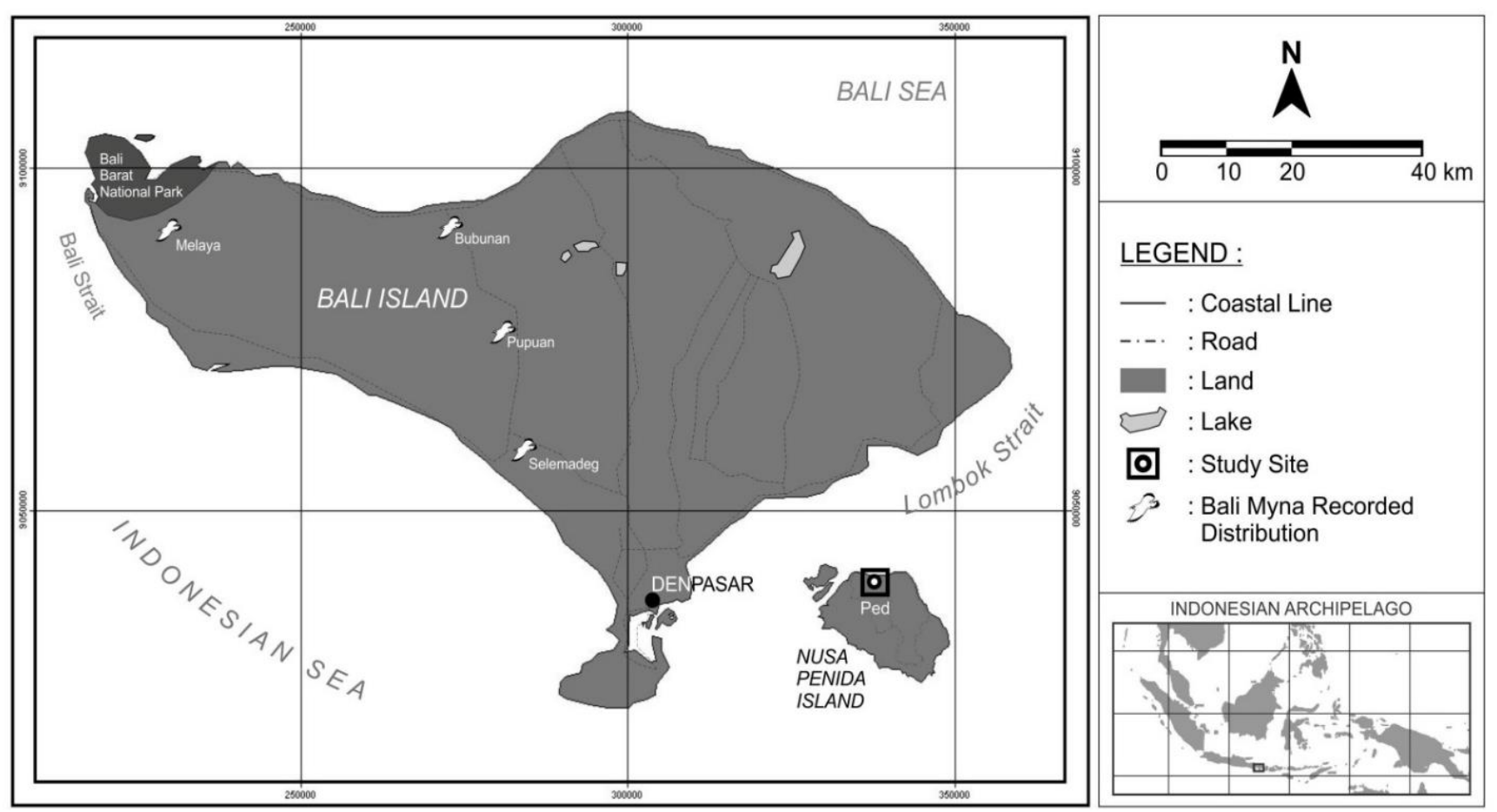

Figure 2. Map showing of study site at agroforestry area in Ped, Nusa Penida, Bali, Indonesia

Observation of interspecific interaction of Bali myna

Interaction of Bali myna with other animals was carried out at their foraging, nesting, and resting areas. Interactions that occurred were recorded, and then classified into competition, predation, and symbiosis.

\section{Data analysis}

Daily activities were presented in a bar chart to compare each Bali myna's daily activity. Vegetation profiles were created manually using millimeter block paper. The home range area was calculated from the total of Bali myna's DAC area using Convex Polygon Method (Gregory 2017).

\section{RESULTS AND DISCUSSION}

\section{Bali myna's daily activities}

The breeding period of Bali myna in Nusa Penida was recorded in January, June, and September (Figure 3). Breeding period includes activities of nesting, brooding, and parenting. Daily activities during the breeding period began by nesting. Birds allocated $2.5 \%$ to $3.5 \%$ of all daily activities for nesting. Nests were made of twigs, dried leaves, and even plastic which were carried with beak into a nest box. The Bali myna in Nusa Penida also nested in a cavity of tree, i.e. Avicennia marina, Arenga pinnata, Artocarpus altilis, Cocos nucifera, Ficus rumphii, Ficus benjamina, Ficus glabella, Leucaena glauca, Tamarindus indica, and Psidium guajava.
Brood activity lasted for 14 days. During the brooding period, they are more in the nest. Brood takes a portion of almost half $(43.3 \%$ to $49.3 \%)$ of all daily activities. Male and female took turns in brood activity, but females did that more frequently than the male. Birds that were not in duty are foraging or wait outside the nest.

After hatching, the next period is parenting which lasted for 21 days. Parenting was $9.0 \%$ to $13.0 \%$ of daily activities. Parenting was carried out alternately between males and females. After 14 days, the young Bali myna comes out of the nest, and started flying. Parenting was continued outside the nest for seven days, before being weaned by the parents.

The main food of Bali myna in Nusa Penida are fruits, insects, and nectar flowers. As much as $31.0 \%$ of fruit feeding was done by Bali myna during period of November to January (Figure 3.A). Bali myna feeds on 12 kinds of fruits. The dominant fruit that was eaten by Bali myna is Artocarpus heterophyllus as much as $44.0 \%$. The fruits of Ficus glabella, Carica papaya, Muntingia calabura, Mangifera indica, and Syzygium cumini are also frequently fed by Bali myna, ranging from $6.0 \%$ to $12.0 \%$ (Figure 4.A). In February to June period, fruit feeding began to decrease to $27.0 \%$, because the fruit season had ended in Nusa Penida. Instead, Bali myna fed on insects, and insect feeding began to increase to $17.8 \%$ (Figure 3.B). Insect feeding was usually done between 10:00 to 14:00 hr. Birds usually fed larvae of Oecophylla smaragdina, Coptotermes curvignathus, Valanga nigricornis, Sarcophaga aurifrons, and Musca domestica. These insects are generally found in trees around the nest or on the body of cattle. In addition to 
fruit and insect feeding, Bali myna also did 5.4\% nectar sucking. In July to October period, nectar sucking increased to $13.4 \%$ (Figure 3.C). Nectar flower sought is Spathodea campanulata. Nectar sucking is usually done between 6:00 to 10:00 hr. Insect feeding was also still widely done in these months, which is $14.0 \%$. The Bali myna was often seen walking and scratching on the ground looking for insects under the litter.
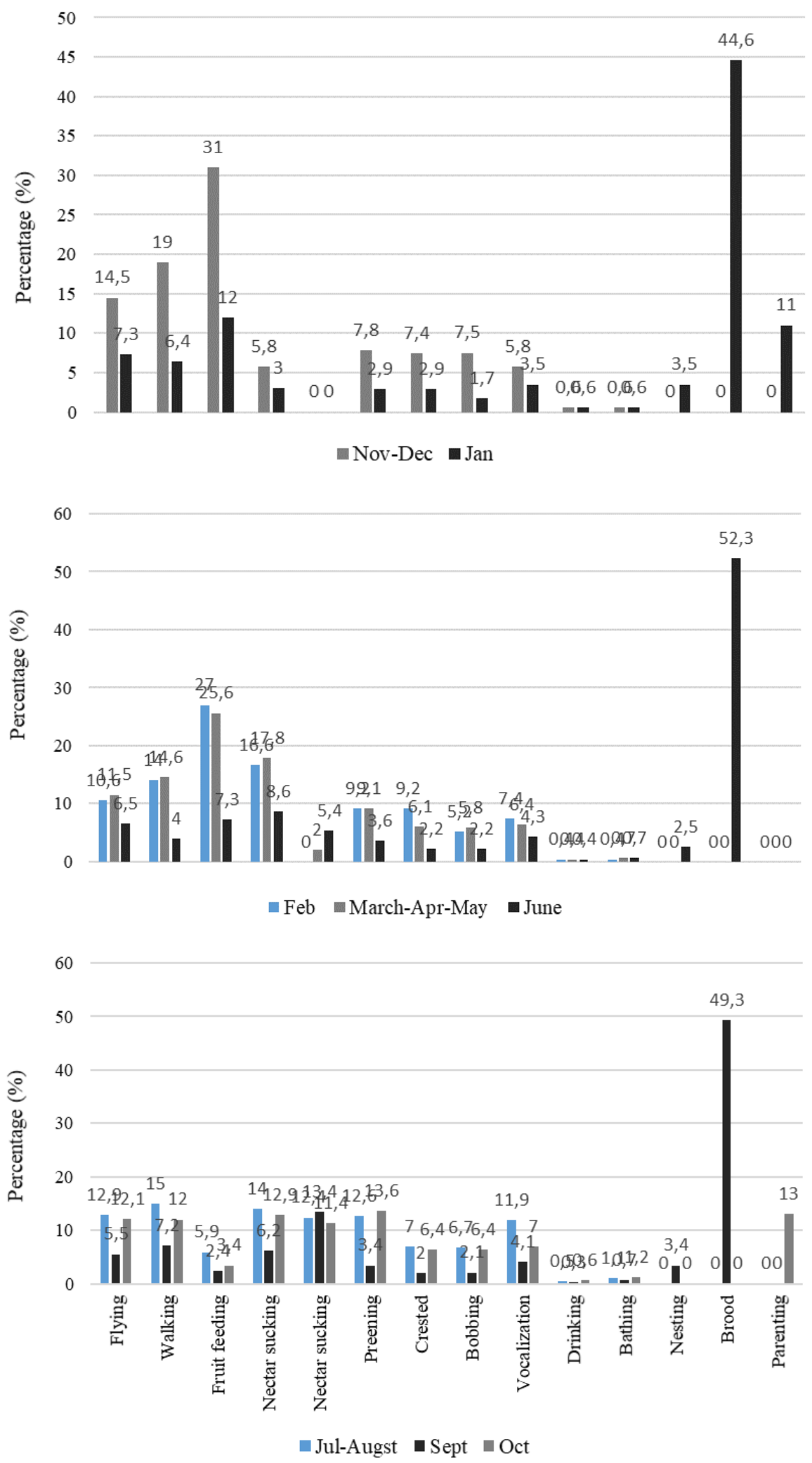

Figure 3. Daily activities of Bali myna (Leucopsar rothschildi) in Nusa Penida, Bali, Indonesia 

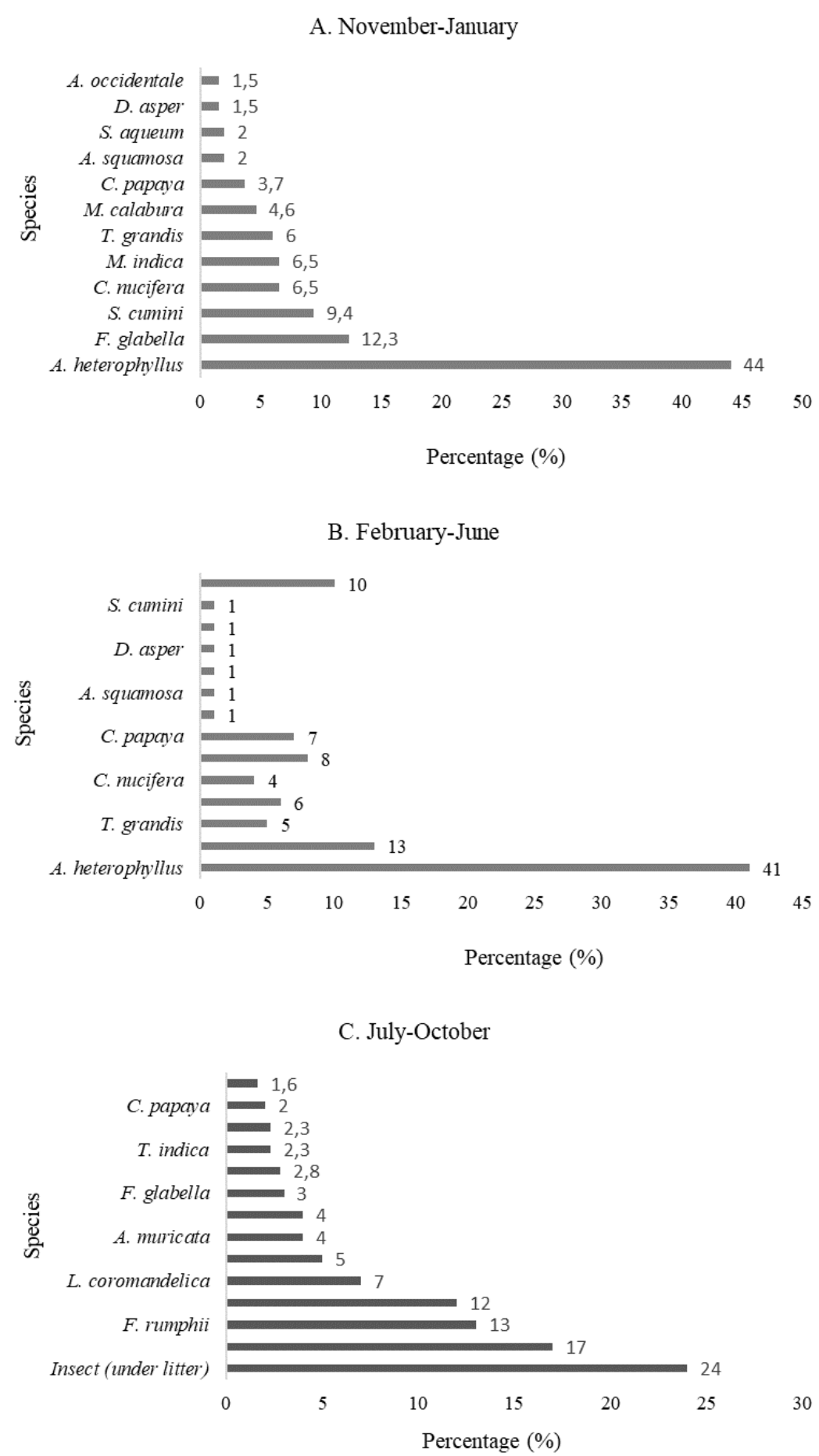

Figure 4. Diet of the Bali myna (Leucopsar rothschildi) in Nusa Penida, Bali, Indonesia

Preening, crested, vocalization, and bobbing activities (Figure 3) were done on the staging tree (Tectona grandis), in the morning after flying from the resting tree (Mangifera indica), and in the afternoon before flying to the resting tree. Preening ( $7.8 \%$ to $13.6 \%)$ is an activity to clean up the feathers. Vocalization was done as much as $5.8 \%$ to $11.9 \%$ of the daily activities. During vocalization, Bali myna raised its crest $(7.0 \%$ to $9.2 \%$ ), and erected the neck feathers while nodding up (bobbing) (5.8\% to $7.5 \%)$. Drinking and bathing activities were carried out between
15:00 to $16: 00 \mathrm{hr}$ as much as $0.3 \%$ to $1.2 \%$, at the water container in the settlement' backyards.

\section{Bali myna's habitat profile}

The vegetation profile of Bali myna's nesting and foraging sites in Nusa Penida (Figure 5a) consisted of a thick and dense canopy layer formed by Artocarpus heterophyllus, Annona muricata, Cananga odorata, Ficus glabella, Gmelina arborea, Gliricidia sepium, M. indica, Morinda citrifolia, and Albizia saman. The average of trees 
height was $15.95 \mathrm{~m}$, with the highest trees was $20 \mathrm{~m}$, namely Gmelina arborea and $M$. indica. The average height of the first branch was $4.3 \mathrm{~m}$, the average canopy width was $5.41 \mathrm{~m}$, the canopy area was $28.19 \mathrm{~m}^{2}$, and the canopy depth was $8.6 \mathrm{~m}$. Lush, dense, and overlapping trees are Artocarpus heterophyllus, Annona muricata, Cananga odorata, Ficus glabella, Gmelina arborea, G. sepium, M. indica, Morinda citrifolia, and Albizia saman. Bali myna's nest was in a nest box that was installed at a height of $8 \mathrm{~m}$ at Artocarpus heterophyllus tree. Fruit is gleaned in all parts of canopy, while insects are hunted at the top of canopy, all parts of the tree, to the litter on the ground.

The vegetation profile of Bali myna resting site was not too dense, composed of two layers of canopy (Figure 5.B). The first canopy layer was composed of $T$. grandis, $M$. indica, Ficus glabella, and Cocos nucifera. The second canopy layer consisted of Muntingia calabura and $M$. indica. The average height of trees was $8.7 \mathrm{~m}$, the average canopy width is $3.9 \mathrm{~m}$, the average canopy length is $3.9 \mathrm{~m}$, the average canopy area was $15.1 \mathrm{~m}^{2}$, and the average canopy depth was $8.6 \mathrm{~m}$. The tallest tree is $T$. grandis of $19.6 \mathrm{~m}$ in height. Bali myna rested in $M$. indica. It was 12 $\mathrm{m}$ in height, length of canopy was $6 \mathrm{~m}$, width of canopy was $5 \mathrm{~m}$, depth of canopy was $7 \mathrm{~m}$, and area of canopy was $30 \mathrm{~m}^{2} . T$. grandis is a staging tree, which is the first or last tree of birds perched, after or before flying from or to a resting's tree. Average of trees on the plot: Ficus glabella 9 trees, M. indica 8 trees, Muntingia calabura 8 trees, Cocos nucifera 4 trees, T. grandis 4 trees, Albizia saman 6 trees, and Annona muricata 6 trees.
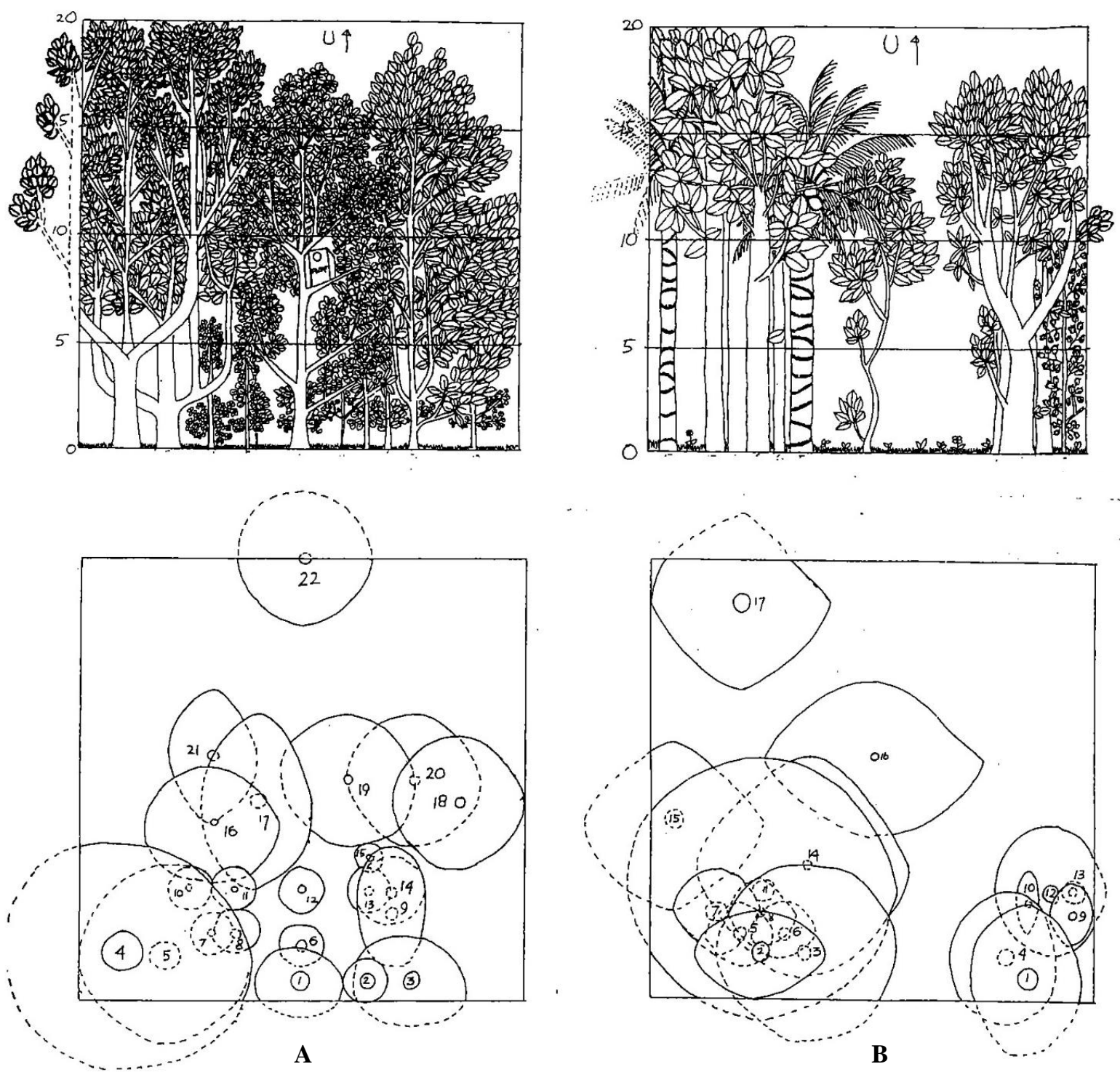

Figure 5. Vegetation profile of Bali myna (Leucopsar rothschildi) in Nusa Penida, Bali, Indonesia. A. Nesting and foraging vegetations composed by: $1^{1)}$ : Artocarpus heterophyllus, 2: Cananga odorata, 3,5: Mangifera indica, 4: Gmelina arborea, 6,11,12,13,15: Annona muricata, 7,8,16,21: Albizia saman, 9,17: Ficus glabella, 10: Gliricidia sepium, 14: Morinda citrifolia, $\left.{ }^{1}\right)$ Nesting tree; B. Resting site vegetations composed by: 1,4,11,12,16 ${ }^{2}$ : Mangifera indica, 2,5,6,7: Tectona grandis, 3,14,15: Cocos nucifera, 8,9,10,13,17: Muntingia calabura, $\left.{ }^{2}\right)$ Resting tree 

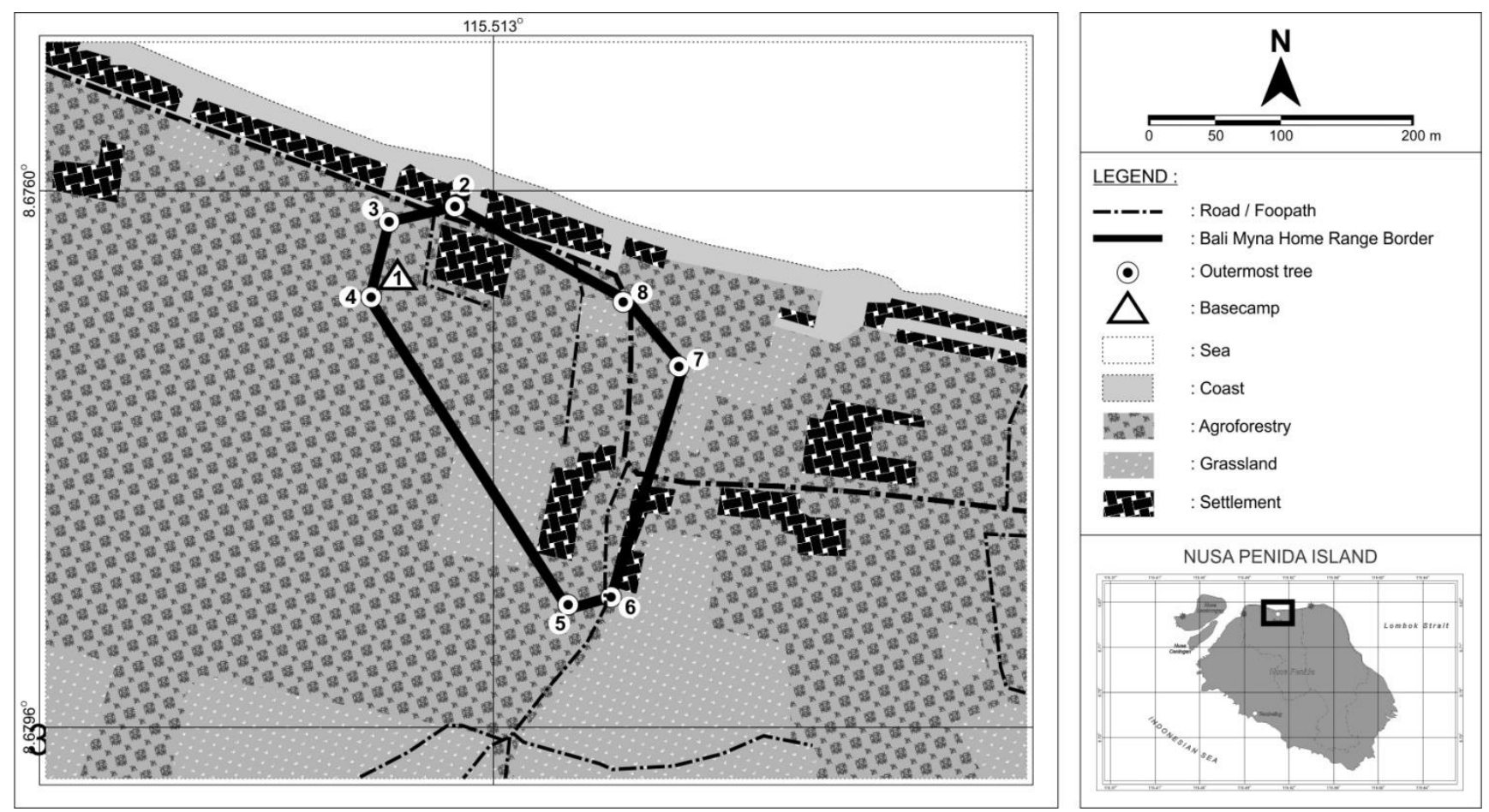

Figure 6. Home range of Bali myna (Leucopsar rothschildi) in Nusa Penida, Bali, Indonesia as much as 3.9 ha. 1: base camp, 2: Mangifera indica (resting tree), 3: Tectona grandis, 4: Mangifera indica, 5: Tectona grandis, 6: Muntingia calabura, 7: Syzygium cumini, 8: Artocarpus heterophyllus (nesting tree)

\section{Bali myna's home range}

The home range of Bali myna's couple in Nusa Penida was 3.9 ha (Figure 6). It consisted of 2.3 ha agroforestry (59\%), grasslands with coconut plantations 0.7 ha (18\%), and settlement 0.9 ha $(23 \%)$. Activities of Bali myna (foraging, resting, and nesting) are mostly done in agroforestry area, which is $94 \%$ of the total area. Grassland is the main habitat of Black-winged starling (Acridotheres melanopterus) and Javan myna (Acridotheres javanicus) to forage insects on the body of castle that grazed there. Bali myna utilized only $3 \%$ of this habitat. Bali myna also used settlement area as much as $3 \%$.

\section{Interspecific interaction of Bali myna}

Bali myna's interaction with other animals in Nusa Penida is in the form of competition, predation, and mutualistic symbiosis. Competition between Bali myna, Black-winged Starling and Javan Myna, was especially to obtain food sources and nesting sites of very often, for example, every morning for sucking nectar. Aggressive behavior often occured in the breeding season. This was observed in Pura Dalem Bungkut, when Bali myna fight with Black-winged starling competing for a nesting site, which was won by Bali myna. Bali myna also often competes with Green-imperial pigeon (Ducula aenea), Sooty-headed bulbul (Pycnonotus aurigaster), and Blacknaped oriole (Oriolus chinensis) for food. Fighting for Competition for water vessel dedicated to drinking and bathing occurred between Bali myna with Sooty-headed bulbul and Spotted dove (Streptopelia chinensis).
Predation of Bali myna by Monitor lizard (Varanus salvator). Monitor lizard preyed on eggs and tillers that were in the nest. During this study, a young of Bali myna was preyed by Monitor lizard in Biaung Village.

Mutualism symbiotic occurs between Bali myna with Bali cattle (Bos javanicus). Bali myna in groups or individuals looking for insects in the body of Bali cattle that are grazed in pastures under coconut plantations. Black-winged starling and Javan myna are the main inhabitants of this prairie habitat, so there is competition between these species with the Bali myna.

\section{Discussion}

The breeding cycles of Bali myna in Nusa Penida is three times a year. Compared to birds in BBNP, where it only breeds once a year, from December to January (Setyaningrum et al. 2015; Sudaryanto et al. 2015), Bali myna in Nusa Penida is more productive. The abundance of foods is thought to cause Bali myna in Nusa Penida to be more productive compared to BBNP. Food quality and availability are one of the most important components influencing fitness (Wilcoxen et al. 2015) and reproduction of birds (Ruffino et al. 2014; Valle et al. 2015; Crates et al. 2016). In the first breeding season (January), diet of Bali myna in Nusa Penida was dominantly on fruits, while in the second season (June) birds feed on fruit and insects, and in the third season (September) birds predominantly feed on insects and nectar. The nectar of $S$. campanulata is a food source of Bali myna which is first reported in this paper. Previously, it was suspected that Bali myna drank water on the $S$. campanulata flower. Insects are also a 
source of food for Bali myna in Nusa Penida obtained on Bali cattle's body, trees, and litter. Looking for insects on the cattle's body is one form of mutualistic symbiosis interaction that occurs between Bali myna with other animals in Nusa Penida. Bali myna in Nusa Penida mostly forages in agroforestry areas (94\%) which provide abundantly and a variety of food sources. In agroforestry there are 45 of those plant species were used for feeding. Ficus glabella, Muntingia calabura, T. grandis, M. indica, and Cocos nucifera are the foraging, resting, and nesting trees for Bali myna. The fruit of Ficus glabella is the main food of Bali myna when the fruit is not in season. There are also many insects on the tree that are sources of food for Bali myna. The holes in the Ficus glabella are often used by Bali myna as a natural nest (Sudaryanto et al. 2015). The existence of holes in trees is one of the important habitat components for Bali myna (Hernowo 2017), because Bali myna cannot make its own holes for nesting. A total of ten nest boxes had been installed in the agroforestry area for Bali myna. The existence of abundant food sources, nesting sites, and roosting trees in agroforestry causes Bali myna to be more active around agroforestry area. This causes the Bali myna's home range in Nusa Penida to be narrower (3.9 ha) compared to 23 hectares in BBNP (Cahyadin 1993), because food sources and nesting sites in BBNP are distributed in large areas (Pramatana et al. 2017). It may imply that habitat quality in Nusa Penida is better than in BBNP. Godet et al. (2018) also proved that a wider home range indicates poor habitat quality, so birds must forage into a wider area, meanwhile daily movement patterns differ between habitats, caused by differences in spatial distribution of resources (Rechetelo et al. 2016). Food availability seems to be an important factor regulating home range dynamics throughout the year (Rühmann et al. 2019). The home range size can also be influenced by competition (Gregory 2017). Competition between Bali myna with Black-winged starling and Javan myna in the grassland makes this area rarely visited (only $3 \%$ ) by Bali myna. Black-winged starling and Javan myna, which are residents in Nusa Penida, seem to be more dominant in grassland area.

The frequency of preening, crested, vocalization, and bobbing activities of Bali myna in Nusa Penida increases towards September, May, and December. This indicates that these activities are part of breeding activities, which in those months was the Bali myna breeding season in Nusa Penida. Male will sing (vocalization) more than usual, raising its crest, and bobbing to attract females. Vocalization is also related to mutual mate guarding, joint resource defense, and signaling commitment (Soma and Iwama 2017). Bobbing in other species of bird is also function in order to keep vision from blurring (Nyakatura and Andrada 2014). Preening activities are done by Bali myna in pairs or individually in the staging tree. Besides clean ectoparasites on the feathers (Bush and Clayton 2018; Koop et al. 2012), preening is also important for signaling quality of mates (Zolnierowicz et al. 2016), and important role in the maintenance of pair bonds (Kenny et al. 2017).

Drinking and bathing activities are done during the day or in hot weather. These activities aim to balance the metabolic system and thermoregulation (Sudaryanto et al. 2015), and clean up feathers from ectoparasites (Clayton et al. 2010; Brooks 2013). When the weather is hot, Bali myna often fights over containers for drinking and bathing with Sooty-headed bulbul and Spotted dove. Another interaction of Bali myna with other animals on Nusa Penida is predation. Animals that have been reported to be predators of Bali myna, besides the Varanus salvator found in this study, are Python reticulatus, Ahaetulla nasuta, Rattus rattus, and Gecko gecko (Sudaryanto et al. 2018).

To conclude, daily activities of Bali myna in Nusa Penida are predominantly done in agroforestry areas, so the home range is relatively narrow, at 3.9 ha. The food types of Bali myna in Nusa Penida are fruits, insects, and nectar flowers. Sucking on nectar flower is the first report here. The vegetation profile of nesting and foraging area for Bali myna consists of one layer of thick and dense canopy, while the vegetation profile of resting area is not too dense trees, which are composed of two canopy layers. Bali myna's interactions with other animals are in the form of competition, predation, and mutualistic symbiosis.

\section{ACKNOWLEDGEMENTS}

Our gratitude goes to Drh. I Gede Nyoman Bayu Wirayudha, CEO of Yayasan Pecinta/Penyantun Taman Nasional or Friends of the National Parks Foundation for advice and all facilities provided during the study. Many thanks to the $5^{\text {th }}$ Earl of Cranbrook and Prof. Yong Hoi Sen for advice as well as spell and grammar-checked.

\section{REFERENCES}

BirdLife International 2018. Leucopsar rothschildi. The IUCN Red List of Threatened Species 2018: e.T22710912A129874226. DOI: 10.2305/IUCN.UK.20182.RLTS.T22710912A129874226.en.

Brooks DM. 2013. Ecology, behavior, and reproduction of an introduced population of Red-vented bulbul (Pycnonotus cafer) in Houston, Texas. Wilson J Ornithol 125: 800-808. DOI: 10.1676/13-037.1.

Bush SE, Clayton DH. 2018. Anti-parasite behaviour of birds. Phil.Trans. R. Soc. B 373: 20170196. DOI: 10.1098/rstb.2017.0196.

Cahyadin Y. 1993. Study on some Ecological Aspects of Bali myna (Leucopsar rothschildi Stresemann, 1912) during Breeding Season in Kelor Bay-West Bali National Park. [Thesis]. University of Padjadjaran, Bandung. [Indonesian]

Convention on International Trade in Endangered Species of Wild Fauna and Flora. 2019. Appendices I, II and III. https://cites.org/eng/app/appendices.php.

Clayton DH, Koop JAH, Harbison CW, Moyer, BR, Bush SE. 2010. How birds combat ectoparasites. J Ornithol 3: 41-71. DOI: 10.2174/1874453201003010041.

Crates RA, Firth JA, Farine DR, Garroway CJ, Kidd LR, Aplin LM, Radersma R, Milligan ND, Voelkl B, Culina A, Verhelst BL, Hinde CA, Sheldon BC. 2016. Individual variation in winter supplementary food consumption and its consequences for reproduction in wild birds. J. Avian Biol. 47: 678-689. DOI: 10.1111/jav.00936

Godet L, Harmange C, Marquet M. Joyeux E, Fournier J. 2018. Differences in home-range sizes of a bird species in its original, refuge, and substitution habitats: challenges to conservation in anthropogenic habitats. Biodivers Conserv. 27: 719-732. DOI: DOI: 10.1007/s10531-017-1460-3.

Gregory T. 2017. Home range estimation. 1-4. DOI: 10.1002/9781119179313.wbprim0177.

Hernowo JB. 2017. Population analysis of Bali myna (Leucopsar rothschildi Stresemann, 1912) released in 2007 in Bali Barat National 
Park, Indonesia. Trop Drylands 1: 83-89. DOI 10.13057/tropdrylands/t010204.

Kementerian Lingkungan Hidup dan Kehutanan. 2018. Regulation of Minister of Environment and Forestry of Republic of Indonesia Number P.106/MENLHK/SETJEN/KUM.1/12/2018 Concerning the Second Amendment to Regulation of Minister of Environment and Forestry of Republic of Indonesia Number P.20/MENLHK/SETJEN/KUM.1/6/2018 Concerning Species of Plants and Animals Protected. http://ksdae.menlhk.go.id/peraturan.html. [Indonesian].

Kenny E, Birkhead TR, Green JP. 2017. Allopreening in birds is associated with parental cooperation over offspring care and stable pair bonds across years. Behav Ecol 28: 1142-1148. DOI: 10.1093/beheco/arx078.

Koop JAH, Huber SK, Clayton DH. 2012. Does sunlight enhance the effectiveness of avian preening for ectoparasite control?. Intl J Parasitol 98: 46-48. DOI: 10.1645/GE-2889.1.

Martin P, Bateson P. 2012. Analysing specific aspects of behavior. In: Martin P, Bateson P (eds.) Measuring Behavior: An Introductory Guide, $3^{\text {rd }}$ ed. Cambridge, United Kingdom. DOI: 10.1017/CBO9780511810893.011.

Nyakatura JA, Andrada E. 2014. On vision in birds: coordination of headbobbing and gait stabilises vertical head position in quail. Front. Zool 11: 27-37. DOI: 10.1186/1742-9994-11-27.

Pramatana F, Prasetyo LB, Rushayati SB. 2017. The habitat susceptibility of Bali starling (Leucopsar rothschildi Stresemann 1912) based on forest fire vulnerability mapping in West Bali National Park. IOP Conf Ser Earth Environ Sci 91: 012003. DOI: 10.1088/17551315/91/1/012003.

Rechetelo J, Grice A, Reside AE, Hardesty BD, Moloney J. 2016. Movement patterns, home range size and habitat selection of an endangered resource tracking species, the Black-throated Finch (Poephila cincta cincta). PLoS ONE 11: e0167254. DOI: 10.1371/journal.pone.0167254

Ruffino L, Salo P, Koivisto E, Banks PB, Korpimäki E. 2014 Reproductive responses of birds to experimental food supplementation: a meta-analysis. Front Zool 11. DOI: 10.1186/s12983-014-0080-y.

Rühmann J, Soler M, Pérez-Contreras T, Ibáñez-Álamo JD. 2019. Territoriality and variation in home range size through the entire annual range of migratory great spotted cuckoos (Clamator glandarius). Sci Rep 9: 6238. DOI: 10.1038/s41598-019-41943-2.

Setyaningrum A, Noviyani P, Suripto BA. 2015. Daily activities of Bali myna (Leucopsar rothschildi) at Bali myna guidance center, Tegal Bunder, Bali Barat National Park. KnE Life Sciences. DOI: 10.18502/kls.v2i1.225

Soma M, Iwama M. 2017. Mating success follows duet dancing in the Java sparrow. PLoS One 12: e0172655. DOI: 10.1371/journal.pone.0172655.

Sudaryanto FX, Djohan TS, Pudyatmoko S, Subagja J. 2015. Behavior Bali starling at Bali Barat National Park and Nusa Penida Island. Vet. J. 16: 364-370.

Sudaryanto FX, Pudyatmoko S, Subagja J, Djohan TS. 2019a. The role of awig-awig of traditional village to Bali starling conservation in Nusa Penida Islands. Jurnal Kajian Bali 9: 227-240. DOI: 10.24843/JKB.2019.v09.i01.p11. [Indonesian]

Sudaryanto FX, Hardini J, Kalih LATTWS, Asrori MM, Suana IW. 2019b. Bird communities and vegetation composition in Nusa Penida, Bali, Indonesia. Biodiversitas 20: 3676-3683. DOI: 10.13057/biodiv/d201229.

Sutito AD, Sumampau T, Prana, M. S. et al. 2012. Monitoring reports Bali starling in Bali Barat National Park. Bali mynah Conservation Society, Bogor [Indonesian].

Valle S, Carpentier E, Vu B, Tsutsui K, Deviche P. 2015. Food restriction negatively affects multiple levels of the reproductive axis in male house finches, Haemorhous mexicanus. J Exp Biol 218: 2694-2704. DOI: $10.1242 /$ jeb.123323.

Van Balen S, Dirgayusa IWA, Putra IMWA, Prins HHT. 2000. Status and distribution of the endemic Bali starling Leucopsar rothschildi. Oryx 34: 188-197. DOI: 10.1046/j.1365-3008.2000.00118.x.

Wilcoxen TE, Horn DJ, Hogan BM, Hubble CN, Huber SJ, Flamm J, Knott M, Lundstrom L, Salik F, Wassenhove SJ, Wrobel ER .2015. Effects of bird-feeding activities on the health of wild birds. Conserv Physiol 3: 1-13. DOI: 10.1093/conphys/cov058.

Yayasan Pecinta/Penyantun Taman Nasional. 2018. Bali Bird Sanctuary \& bali starling conservation on Nusa Penida, Bali. https://www.fnpf.org/what-we-do/nusa-penida-bali/wildlife/balistarling-conservation-project?lang=id.

Zolnierowicz KM, Nyklova-Ondrova M, Tobolka M. 2016. Sex differences in preening behaviour in the White stork Ciconia ciconia. Pol J Ecol 64: 431-435. DOI: 10.3161/15052249PJE2016.64.3.012 